\title{
HEMATOLOGICAL AND BIOCHEMICAL ALTERATIONS INDUCED BY TRAMADOL ADMINISTRATION IN MALE ALBINO RATS
}

\author{
AZIZA A.M. EL-SHAFEY; MOSHIRA M.E. SELIEM; DOAA S. IBRAHIM \\ AND HAITHAM A.S. IBRAHIM
}

Department of Zoology, Faculty of Science, Benha University, Egypt.

Received: 11 March 2019; Accepted: 20 March 2019

\begin{abstract}
The use of analgesics to alleviate the severe pains associated with many diseases is necessary. It is therefore important to study the effects of administration these analgesics to determine the side effects for their use. Hence we decided to study the hematological and biochemical effects of tramadol and tramadol withdrawal on male albino rats. Rats were divided into four control rat groups ( 7 rats each), and four tramadol rat groups (7 rats each); two groups administrated a daily oral dose of tramadol $(20 \mathrm{mg} / \mathrm{kg} \mathrm{b} . w \mathrm{t})$ for 30 and 60 days and two groups also administrated a daily oral dose of tramadol for 30 and 60 days then tramadol withdrawal for 7 days. Hemoglobin $(\mathrm{Hb})$ content, red blood cells (RBCs) count, hematocrit (Hct) value, and lipid profile decreased, while white blood cells (WBCs) and platelets counts, liver function enzymes, and kidney function parameters increased after tramadol administration. Most parameters improved after tramadol withdrawal. The study showed the harmful effects of tramadol on the hematological and biochemical parameters and the effects of improvement on rats after tramadol withdrawal from them, especially after a short period.
\end{abstract}

Key words: Tramadol; hematological parameters; liver function enzymes; kidney function parameters; lipid profile.

\section{INTRODUCTION}

Analgesics are a group of drugs that act in different ways on the central nervous system to analgesia and relief from pain (Kumar et al., 2010). In moderate and severe pain cases, opioid analgesic drugs are mainly used (El Shal and Selim, 2015). Opioid analgesic drugs might be obtained from natural sources (e.g. morphine, codeine) or from synthetic sources (as Tramadol, heroin, Hussein et al., 2017a).

Nowadays, tramadol is widely used as an analgesic drug in human medicine (Azari et al., 2014). Its mechanism of action is based on the inhibition of ascending pain to the central nervous system by its binding to $\mu$ - opiate receptors and inhibit the reuptake of norepinephrine and serotonin (Aldalou et al., 2014). Continuous tramadol administration leads to the appearance of its toxic effects on various organs of the body (Shadnia et al., 2008). Tramadol

Corresponding author: Dr. DOAA S. IBRAHIM E-mail address: Doaa.mohamed@fsc.bu.edu.eg Present address: Department of Zoology, Faculty of Science, Benha University, Egypt. has toxic effects on the structure and function of hepatic, renal and testicular tissues of male albino rats (Youssef and Zidan, 2016). In addition, the neurotoxicity of tramadol has been reported by Hussein et al. (2017b). High doses of tramadol cause neuronal degeneration in the rat brain (Atici et al., 2005) and alter brain neurotransmitter levels (Bloms-Funke et al., 2011).

This study aims to investigate the effects of administration a daily oral dose $(20 \mathrm{mg} / \mathrm{kg}$ b.wt $)$ of tramadol for 30 and 60 days on the hematological and biochemical parameters and the tramadol withdrawal effects.

\section{MATERIALS AND METHODS}

\section{Tramadol}

Tramadol tablets were obtained from Sigma Pharmaceuticals Industries Company (Quesna, El Mnoufia, Egypt). It was orally administered daily $(20 \mathrm{mg} / \mathrm{kg}$ b.wt) as previously used by El-Baky and Hafez (2017).

\section{Animals}

Rats were divided into four control rat groups (7 rats each), and four tramadol rat groups (7 rats each); two groups administrated tramadol for 30 and 60 
days and two groups administrated tramadol for 30 and 60 days then stayed in the experimental conditions for 7 days.

\section{Blood sampling}

After the experiment period, all fasted overnight rats were anesthetized. Then, rats blood samples were collected from posterior vena cava in two groups of tubes, the first tubes group were containing EDTA as an anticoagulant for determination of the hematological parameters, while the blood in the second tubes group was allowed to clot without using any anticoagulants for $1-2 \mathrm{~h}$ at $37^{\circ} \mathrm{C}$ then centrifuged at $3000 \mathrm{rpm}$ for 15 minutes. Sera were separated and stored at $-20{ }^{\circ} \mathrm{C}$ for determination of the biochemical parameters.

\section{Determination of hematological parameters}

A complete blood count performed using an automated hematology cell counter (Mindray BC2800).

\section{Determination of biochemical parameters:}

Using a semi-automated blood chemistry analyzer (Mindray BA-88A) the following biochemical parameters were performed.

Serum aspartate aminotransferase (AST) and alanine aminotransferase (ALT) activities were determined kinetically according to Tietz (1976) by using BioMed Company kit.

Serum urea and creatinine levels were determined spectrophotometrically according to Tabacco et al. (1979) and Murray (1984), respectively by using Diamond Company kit.

Serum triglycerides (TG), total cholesterol (TC), and high-density lipoprotein cholesterol (HDL-C) concentrations were measured spectrophotometrically according to Bucolo and David (1973), Meiattini et al. (1978) and Grove (1979), respectively by using Spinreact Company kits. The concentration of low-density lipoprotein cholesterol (LDL-C) was calculated by the equations of Friedewald et al. (1972).

\section{Statistical analysis}

All parameter values were expressed as the mean \pm standard deviation. Statistical analysis was conducted by one-way ANOVA using the computer program Statistical Package for Social Science (SPSS, Version 20.00, Chicago, USA) followed by Least Significant Difference (LSD) test.

\section{RESULTS}

Hemoglobin $(\mathrm{Hb})$ contents in all tramadol groups significantly decreased $(\mathrm{p}<0.05)$ in comparison with their control groups. In addition, tramadol withdrawal from the group that administrated tramadol for 60 days showed significant improvement in $\mathrm{Hb}$ content. Also, the count of red blood cells (RBCs) in all tramadol groups except in the group that administrated tramadol for 30 days decreased compared to their control groups. Both the group that administrated tramadol for 60 days and its withdrawal group showed low hematocrit (Hct) values. The count of white blood cells (WBCs) in all tramadol groups except in the group that administrated tramadol for 30 days increased compared to their control groups. In addition, tramadol withdrawal from the group that administrated tramadol for 30 days showed a significant increase in WBCs content. Blood platelets count significantly increased in the group that administrated tramadol for 30 days (Table 1 ).

All tramadol groups except in the group that administrated tramadol for 30 days have high activities of ALT compared to their control groups. Also, all tramadol groups except in the tramadol withdrawal group $(60+7$ days $)$ have high activities of AST compared to their control groups. Activities of ALT and AST significantly decreased in the two tramadol withdrawal groups (Table 2).

Serum urea levels were high in all tramadol groups except in the group that administrated tramadol for 60 days compared to their control groups. The level of serum urea significantly decreased after tramadol withdrawal period from the group that administrated tramadol for 30 days. In addition, both tramadol administration groups have high levels of serum creatinine compared to their control groups. After the tramadol withdrawal period, serum creatinine levels significantly decreased in the two tramadol withdrawal groups (Table 3 )

After 60 days of tramadol administration, serum triglycerides (TG) level significantly decreased $(p<0.05)$ compared to its control group. Tramadol withdrawal from the group that administrated tramadol for 30 days decreased the TG level. Both tramadol administration groups have low levels of TC and LDL-C compared to their control groups. While the levels of TC and LDL-C significantly increased after tramadol withdrawal from the group that administrated tramadol for 30 days. Both the group that administrated tramadol for 30 days and the tramadol withdrawal group $(60+7$ days $)$ showed low HDL-C levels compared to their control groups. Tramadol withdrawal from the group that administrated tramadol for 30 days increased the HDL-C level (Table 4). 
Table 1: Effects of daily oral administrations of tramadol (20 mg/kg b.wt.) for 30 and 60 days and after 7 days of withdrawal on hematological parameters in male rats.

\begin{tabular}{|c|c|c|c|c|c|}
\hline \multirow{2}{*}{ Parameters } & \multirow{2}{*}{ Groups } & \multicolumn{2}{|c|}{ Administration period } & \multicolumn{2}{|c|}{ ( Administration + Withdrawal) period } \\
\hline & & 30 days & 60 days & $30+7$ days & $60+7$ days \\
\hline \multirow{2}{*}{ Hb (g/dl) } & Control & $15.03 \pm 0.15$ & $15.13 \pm 0.48$ & $15.35 \pm 0.64$ & $16.03 \pm 0.30$ \\
\hline & Tramadol & $13.48 \pm 0.17^{*}$ & $12.10 \pm 0.39^{*}$ & $13.62 \pm 0.62^{*}$ & $12.83 \pm 0.29^{* \mathrm{~B}}$ \\
\hline \multirow{2}{*}{$\begin{array}{l}\text { RBCs } \\
\left(\mathbf{1 0}^{6} / \mathbf{m m}^{3}\right)\end{array}$} & Control & $7.30 \pm 0.06$ & $7.65 \pm 0.44$ & $7.71 \pm 0.40$ & $7.75 \pm 0.31$ \\
\hline & Tramadol & $7.20 \pm 0.14$ & $6.05 \pm 0.13^{*}$ & $7.29 \pm 0.24^{*}$ & $6.28 \pm 0.28^{*}$ \\
\hline \multirow{2}{*}{ Het $(\%)$} & Control & $43.15 \pm 0.90$ & $45.75 \pm 3.50$ & $43.24 \pm 1.08$ & $46.50 \pm 1.29$ \\
\hline & Tramadol & $43.05 \pm 0.61$ & $36.25 \pm 2.63^{*}$ & $43.11 \pm 1.55$ & $37.50 \pm 1.30^{*}$ \\
\hline \multirow{2}{*}{$\begin{array}{l}\text { WBCs } \\
\left(10^{3} / \mathbf{m m}^{3}\right)\end{array}$} & Control & $9.92 \pm 0.87$ & $8.23 \pm 0.34$ & $8.90 \pm 1.44$ & $9.1 \pm 1.17$ \\
\hline & Tramadol & $10.80 \pm 0.42$ & $12.78 \pm 0.70^{*}$ & $12.60 \pm 0.65^{* \mathrm{~A}}$ & $13.43 \pm 1.46^{*}$ \\
\hline \multirow{2}{*}{$\begin{array}{l}\text { Platelets } \\
\left(10^{3} / \mathbf{m m}^{3}\right)\end{array}$} & Control & $742.00 \pm 16.40$ & $616.50 \pm 36.5$ & $801.50 \pm 59.05$ & $675.5 \pm 47.06$ \\
\hline & Tramadol & $857.25 \pm 27.20^{*}$ & $663.50 \pm 41.5$ & $808.00 \pm 44.92$ & $642.0 \pm 59.83$ \\
\hline
\end{tabular}

Values are expressed as means \pm standard deviation for seven rats.

* Significant difference between control and tramadol groups at $\mathrm{P}<0.05$.

${ }^{\mathrm{A}}=$ Significant difference between tramadol administration (30 days) and tramadol withdrawal $(30+7$ days $)$ groups at $\mathrm{P}<0.05$.

$\mathrm{B}=$ Significant difference between tramadol administration (60 days) and tramadol withdrawal $(60+7$ days $)$ groups at $\mathrm{P}<0.05$.

Table 2: Effects of daily oral administrations of tramadol (20 mg/kg b.wt.) for 30 and 60 days and after 7 days of withdrawal on liver function enzymes in male rats.

\begin{tabular}{cccccc}
\hline \multirow{2}{*}{ Parameters } & \multirow{2}{*}{ Groups } & \multicolumn{2}{c}{ Administration period } & \multicolumn{2}{c}{ (Administration + Withdrawal) period } \\
\cline { 2 - 6 } & & $\mathbf{3 0}$ days & $\mathbf{6 0}$ days & $\mathbf{3 0}+\mathbf{7}$ days & $\mathbf{6 0}+\mathbf{7}$ days \\
\hline \multirow{2}{*}{ ALT (U/L) } & Control & $48.00 \pm 3.16$ & $68.50 \pm 2.08$ & $41.75 \pm 3.09$ & $51.75 \pm 2.22$ \\
\cline { 2 - 6 } & Tramadol & $51.75 \pm 0.50$ & $92.00 \pm 4.08^{*}$ & $45.25 \pm 0.50^{* \mathrm{~A}}$ & $86.25 \pm 3.86^{* \mathrm{~B}}$ \\
\hline \multirow{2}{*}{ AST (U/L) } & Control & $143.00 \pm 7.78$ & $147.00 \pm 2.94$ & $136.00 \pm 5.48$ & $130.15 \pm 4.27$ \\
\cline { 2 - 6 } & Tramadol & $196.00 \pm 17.14^{*}$ & $195.50 \pm 4.20^{*}$ & $139.50 \pm 5.80^{\mathrm{A}}$ & $140.75 \pm 3.09^{* \mathrm{~B}}$ \\
\hline
\end{tabular}

Values are expressed as means \pm standard deviation for seven rats.

* Significant difference between control and tramadol groups at $\mathrm{P}<0.05$.

${ }^{A}=$ Significant difference between tramadol administration (30 days) and tramadol withdrawal $(30+7$ days $)$ groups at $\mathrm{P}<0.05$.

${ }_{\mathrm{B}}^{\mathrm{B}}=$ Significant difference between tramadol administration (60 days) and tramadol withdrawal $(60+7$ days $)$ groups at $\mathrm{P}<0.05$

Table 3: Effects of daily oral administrations of tramadol (20 mg/kg b.wt.) for 30 and 60 days and after 7 days of withdrawal on kidney function parameters in male rats.

\begin{tabular}{|c|c|c|c|c|c|}
\hline \multirow{2}{*}{ Parameters } & \multirow{2}{*}{ Groups } & \multicolumn{2}{|c|}{ Administration period } & \multicolumn{2}{|c|}{ (Administration + Withdrawal) period } \\
\hline & & 30 days & 60 days & $30+7$ days & $60+7$ days \\
\hline \multirow[t]{2}{*}{ Urea (mg/dl) } & Control & $35.50 \pm 1.29$ & $46.75 \pm 3.40$ & $44.50 \pm 4.04$ & $38.00 \pm 2.94$ \\
\hline & Tramadol & $62.75 \pm 5.38^{*}$ & $50.00 \pm 2.16$ & $56.75 \pm 2.99^{* \mathrm{~A}}$ & $47.25 \pm 2.50^{*}$ \\
\hline \multirow{2}{*}{$\begin{array}{l}\text { Creatinine } \\
\text { (mg/dl) }\end{array}$} & Control & $0.82 \pm 0.08$ & $0.80 \pm 0.07$ & $0.89 \pm 0.03$ & $0.88 \pm 0.09$ \\
\hline & Tramadol & $1.27 \pm 0.10^{*}$ & $1.23 \pm 0.10^{*}$ & $0.94 \pm 0.02^{\mathrm{A}}$ & $0.92 \pm 0.09^{\mathrm{B}}$ \\
\hline
\end{tabular}

Values are expressed as means \pm standard deviation for seven rats.

* Significant difference between control and tramadol groups at $\mathrm{P}<0.05$.

${ }^{\mathrm{A}}=$ Significant difference between tramadol administration (30 days) and tramadol withdrawal $(30+7$ days $)$ groups at $\mathrm{P}<0.05$.

$\mathrm{B}=$ Significant difference between tramadol administration (60 days) and tramadol withdrawal $(60+7$ days $)$ groups at $\mathrm{P}<0.05$. 
Table 4: Effects of daily oral administrations of tramadol (20 mg/kg b.wt.) for 30 and 60 days and after 7 days of withdrawal on the lipid profile parameters in male rats.

\begin{tabular}{|c|c|c|c|c|c|}
\hline \multirow{2}{*}{ Parameters } & \multirow{2}{*}{ Groups } & \multicolumn{2}{|c|}{ Administration period } & \multicolumn{2}{|c|}{ ( Administration + Withdrawal) period } \\
\hline & & 30 days & 60 days & $30+7$ days & $60+7$ days \\
\hline \multirow{2}{*}{ TG (mg/dl) } & Control & $112.25 \pm 7.85$ & $106.50 \pm 4.79$ & $99.75 \pm 4.79$ & $93.50 \pm 3.69$ \\
\hline & Tramadol & $106.00 \pm 6.68$ & $94.50 \pm 2.08^{*}$ & $95.00 \pm 1.41^{\mathrm{A}}$ & $91.75 \pm 3.50$ \\
\hline \multirow[t]{2}{*}{ TC (mg/dl) } & Control & $96.00 \pm 4.24$ & $117.75 \pm 4.35$ & $110.25 \pm 3.77$ & $120.75 \pm 2.98$ \\
\hline & Tramadol & $84.25 \pm 6.13^{*}$ & $92.50 \pm 3.11^{*}$ & $106.25 \pm 5.12^{\mathrm{A}}$ & $117.50 \pm 2.65$ \\
\hline \multirow{2}{*}{$\begin{array}{l}\text { HDL-C } \\
(\mathrm{mg} / \mathrm{dl})\end{array}$} & Control & $58.25 \pm 2.50$ & $30.75 \pm 1.71$ & $59.75 \pm 3.09$ & $38.50 \pm 3.11$ \\
\hline & Tramadol & $38.75 \pm 0.96^{*}$ & $30.00 \pm 2.16$ & $55.25 \pm 3.09^{\mathrm{A}}$ & $34.25 \pm 2.75^{*}$ \\
\hline \multirow{2}{*}{$\begin{array}{l}\text { LDL-C } \\
(\mathbf{m g} / \mathbf{d l})\end{array}$} & Control & $27.75 \pm 2.50$ & $34.25 \pm 2.50$ & $29.00 \pm 2.58$ & $30.25 \pm 1.70$ \\
\hline & Tramadol & $21.35 \pm 4.27^{*}$ & $24.50 \pm 1.29^{*}$ & $27.15 \pm 3.59^{\mathrm{A}}$ & $28.90 \pm 3.56$ \\
\hline
\end{tabular}

Values are expressed as means \pm standard deviation for seven rats.

* = Significant difference between control and tramadol groups at $\mathrm{P}<0.05$.

${ }^{\mathrm{A}}=$ Significant difference between tramadol administration (30 days) and tramadol withdrawal $(30+7$ days $)$ groups at $\mathrm{P}<0.05$.

$\mathrm{B}=$ Significant difference between tramadol administration (60 days) and tramadol withdrawal $(60+7$ days $)$ groups at $\mathrm{P}<0.05$.

\section{DISCUSSION}

Our results showed decreases in $\mathrm{Hb}$ content, $\mathrm{RBCs}$ count, and Hct value after administration of tramadol (20 mg/kg b.wt.) for 30 and 60 days. Our findings agreed with those of Aldalou et al. (2014), who found that administration of sildenafil (1.40 $\mathrm{mg} / \mathrm{kg} /$ day) and tramadol (4 mg/kg/day) for 25 days to rabbits led to significant decreases in RBCs count and $\mathrm{Hb}$ content. The decrease in the RBCs count may be due to the inhibitory effect of tramadol on erythropoiesis (Aldiwan et al., 2015). In addition, the WBCs count increased after administration of tramadol to rats. Aldiwan et al. (2015) explained the elevation in the WBCs count by the activation of defense immune system. While Aldalou et al. (2014) reported that high lymphocyte percentage in male rats injected by tramadol $(100 \mathrm{mg} / \mathrm{kg})$ for 30 days was the reason behind the WBCs count elevation.

Our data confirm that tramadol administration increased the activities of liver function enzymes (ALT and AST). The high levels of the liver enzymes in circulation indicated the severity of the liver damage (Simeon and Abbey, 2018). Also, tramadol causes severe cellular toxicity and liver failure (Elmanama et al., 2015). Aldalou et al. (2014), observed that sildenafil and tramadol administration might be responsible for impaired liver function. Tramadol administration was associated with hepatic congestion, hemorrhage and necrosis in the male rats (Loughrey et al., 2003). After tramadol withdrawal, activities of ALT and AST decreased which is a marker for improving liver functions. Nna et al. (2015) observed that the hepatotoxicity of tramadol $(2 \mathrm{mg} / 100 \mathrm{~g} \mathrm{~b}$.w., for 8 weeks) is reversed after withdrawal it for 8 weeks.

Our results showed elevations of serum urea and creatinine after tramadol administration. Nephrotoxicity induced by tramadol might be responsible for kidney dysfunction (Aldiwan et al., 2015). The high blood urea after tramadol treatment might be due to the destruction of RBCs (Aldalou et al., 2014). Also, a histopathological study reported the toxicity effect of tramadol on kidney tissue that represented in glomerular hemorrhage, atrophied glomeruli, wide Bowman's space, degenerated tubules and cellular infiltration (Youssef and Zidan, 2016).

Lipid profile parameters were decreased significantly in response to tramadol administration and increased after its withdrawal. The previous result agreed with Ahmed and Kurkar (2014) who demonstrated that tramadol reduced serum concentration of total cholesterol. The explanation of this observed may be based on the action of tramadol on lipid metabolism or lipid peroxidation (Aldalou et al., 2014). Tramadol may inhibit cholesterol synthesis (Nna et al., 2016). 


\section{CONCLUSION}

Administration a daily oral dose $(20 \mathrm{mg} / \mathrm{kg}$ b.wt $)$ of tramadol for 30 and 60 days caused harmful effects on the hematological and biochemical parameters. Improvement of these parameters appeared after tramadol withdrawal, especially after a short period.

\section{REFERENCES}

Ahmed, M.A. and Kurkar, A. (2014): Effects of opioid (tramadol) treatment on testicular functions in adult male rats: The role of nitric oxide and oxidative stress. Clin. Exp. Pharmacol. Physiol., 41: 317-323.

Aldalou, A.R.; Abdel-Aziz, I. and Shahwan, O. (2014): Impact of giving sildenafil (viagra) / tramadol (tramal) combination on the blood of domestic rabbits. J. Sci., 4 (3): 162-169.

Aldiwan, M.A.; Alzobidy, A.M.H. and Younis, M.A. (2015): The effect of Tramadol on some blood and biochemical parameters of male rats (Rattus norvegicus). Baghdad Sci. J., 12(3): 496-502.

Atici, S.; Cinel, I.; Cinel, L.; Doruk, N.; Eskandari, G. and Oral, U. (2005): Liver and kidney toxicity in chronic use of opioids: An experimental long term treatment model. J. Biosci., 30(2): 245-252.

Azari, O.; Emadi, L.; Kheirandish, R.; Bafti, H.S.; Nejad, M.R.E. and Faroghi, F. (2014): The effects of long-term administration of tramadol on epididymal sperm quality and testicular tissue in mice. Iranian J. Veteran. Surg., 9 (1): 23-30.

Bloms-Funke, P.; Dremencov, E.; Cremers, T.I. and Tzschentke, T.M. (2011): Tramadol increases extracellular levels of serotonin and noradrenaline as measured by in vivo microdialysis in the ventral hippocampus of freely-moving rats. Neurosci. Lett., 490 (3): 191-195.

Bucolo, G. and David, M. (1973): Quantitative determination of serum triglycerides by use of enzymes. Clin. Chem., 19: 476-482.

El Shal, E.B. and Selim, M.M.H. (2015): The effect of tramadol treatment on rat testes and the possible protective role of selenium (light and electron microscopic study. Al-Azhar Assiut Med. J., 13 (1): 127-137.

El-Baky, A.E.A. and Hafez, M.M. (2017): NOS expression in oxidative stress, neurodegeneration and male infertility induced by the abuse of tramadol. Biochem. Pharmacol., 6: 223. doi: 10.4172/21670501.1000223 .

Elmanama, A.A.; Abu-Tayyem, N.E.S.; Essawaf, N.N. and Hmaid, I.M. (2015): Tramadol induced liver and kidney toxicity among abusers in gaza strip, palestine. Jordan J. Biol. Sci., 8: 133-137.

Friedewald, W.T.; Levy, R.I. and Fredrickson, D.S. (1972): Estimation of the concentration of low-density lipoprotein cholesterol in plasma, without use of the preparative ultracentrifuge. Clin. Chem., 18: 499-502.

Grove, TH. (1979): Effect of reagent $\mathrm{pH}$ on determination of high density lipoprotein cholesterol by precipitation with sodium phosphotungstate- magnesium. Clin. Chem., 25: 560-564.

Hussein, S.A.; Abdel Aal, S.A. and Ismail, H.K. (2017a): Effect of tramadol drug on some biochemical and immunological parameters in albino male rats; evaluation of possible reversal following its withdrawal. Benha Vet. Med. J., 33 (2): 418-429.

Hussein, S.A.; Abdel Aal, S.A. and Ismail, H.K. (2017b): Neurodegeneration and oxidative stress induced by tramadol administration in male rats: The effect of its withdrawal Benha Vet. Med. J., 33 (2): 149-159.

Kumar, M.; Shete, A. and Akbar, Z. (2010): A Review on analgesic: from natural sources. Int. J. Pharm. Biol. Sci. Arch., 1 (2): 95100.

Loughrey, M.B.; Loughrey, C.M.; Johnston, S. and Rourke, D. (2003): Fatal hepatic failure following accidental tramadol overdose. Forensic Sci. Int., 134: 232-233.

Meiattini, F.; Prencipe, $L$. and Bardelli, $F$. (1978): The 4-hydroxy-benzoate/4aminophenazone chromogenic system used in the enzymatic determination of serum cholesterol. Clin. Chem., 24: 2161-2165.

Murray, R.L. (1984): Creatinine. Kaplan A et al. The C.V. Mosby Company St Louis. Toronto. Princeton, Clin. Chem., 1261-1266.

Nna, V.U.; Akpan, U.P. and Osim, E.E. (2016): Hyperprolactinemia contributes to reproductive deficit in male rats chronically administered PDE5 inhibitors (sildenafil and tadalafil) and opioid (tramadol). Asian Pac. J. Reprod., 5 (5): 381-386.

Nna, V.U.; Akpan, U.P.; Okon, V.E. and Atangwho, I.J. (2015): Hepatotoxicity following separate administration of two phosphodiesterase-5 inhibitors (sildenafil and tadalafil) and opioid (tramadol); evaluation of possible reversal following their withdrawal. J. Applied Pharma. Sci., 5 (8):105-113.

Shadnia, S.; Soltaninejad, K.; Heydari, $K$.; Sasanian, G. and Abdollahi, M. (2008): Tramadol intoxication: a review of 114 cases. Hum. Exp. Toxicol., 27: 201-205.

Simeon, G.G. and Abbey, S.T. (2018): Some marker enzymes and histological alteration on the administration of tramadol hydrochloride on rat liver. Mod. Res. Inflamm., 7: 9-20. 
Tabacco, A.; Meiattini, F.; Moda, E. and Tarli, P. (1979): Simplified enzymic/colorimetric serum urea nitrogen determination. Clin. Chem., 25(2): 336-337.

Tietz, N.W. (1976): Fundamentals of clinical chemistry Philadelphia, W.B., Saunders, Pp. 923-929.
Youssef, S.H. and Zidan, A.H.M. (2016): Histopathological and biochemical effects of acute and chronic tramadol drug toxicity on liver, kidney and testicular function in adult male albino rats. J. Med. Toxicol. Clin. Forensic Med., 1: 1-7.

\section{التغيرات الاموية والبيوكيميائية لتعاطى الترامادول على ذكور الجرذان البيضاء}

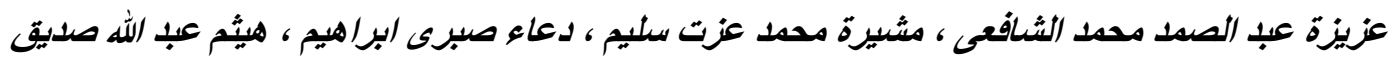

E-mail: Doaa.mohamed@fsc.bu.edu.eg Assiut University web-site: www.aun.edu.eg

إن استخدام المسكنات لتخفيف الآلام الثديدة المرتبطة بالعديد من الأمراض يعد من الأمور الضرورية واللازمة لتخفيف آلام

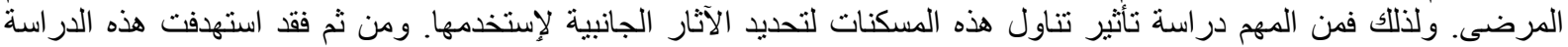

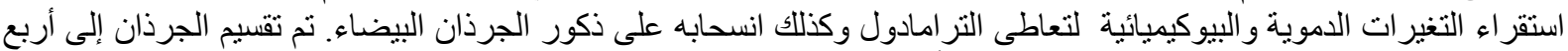

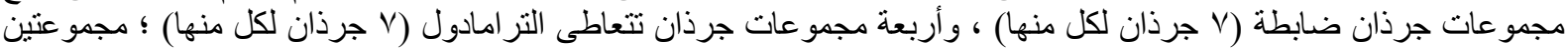

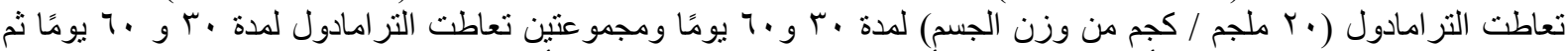

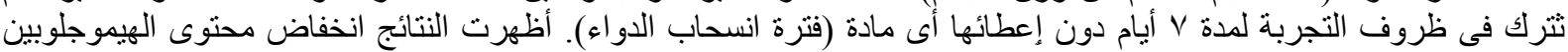

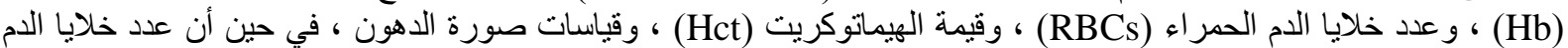

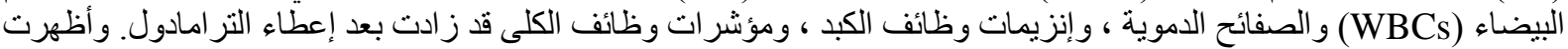

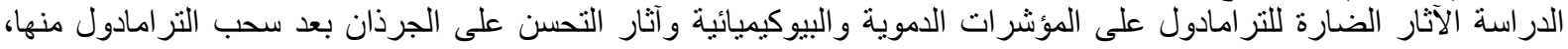

